\title{
Stan martwego drewna na terenie Puszczy Niepołomickiej jako wynik długotrwałego użytkowania lasu i krótkotrwałej ochrony w ramach sieci Natura 2000
}

\author{
Jan Holeksa, Pawee Kapusta, Ewa Budziakowska-Kubik, Katarzyna Izworska, \\ PrZEMYSŁaW KureK, ŁuKasZ PiechniK, Grażyna SZAREK-ŁUKASZEWSKA, \\ Maria Wojterska, Tomasz Zielonka i Magdalena ŻywieC
}

\begin{abstract}
Holeksa, J., Kapusta, P., Budziakowska-Kubik, E., Izworska, K., Kurek, P., Piechnik, Ł., SzareK-Łukaszewska, G., Wojterska, M., ZielonkA, T. AND ŻywIEC, M. 2020. Stock of deadwood in the Niepołomice Forest as a result of long-term forest use and short-term protection within the Natura 2000 network. Fragmenta Floristica et Geobotanica Polonica 27(1): 119-139. Kraków. e-ISSN 2449-8890, ISSN 1640-629X.

ABSTRACT: Recently, commercial forests have been proposed to play a greater role in increasing the stock of deadwood. This causes a conflict between the biological and economic benefits of these forests. To find a solution to this problem in a large Natura 2000 area in southern Poland, we analyzed the relationship between stand properties and the quantity and quality of deadwood. On average, 184 pieces of deadwood were recorded per 1 ha. The average volume of snags and logs was $6.7 \mathrm{~m}^{3} \mathrm{ha}^{-1}$. The volume was $9.2 \mathrm{~m}^{3} \mathrm{ha}^{-1}$ if stumps were included. In black alder forests the volume was higher than elsewhere. Stump volume was highest in the youngest stands, but the volume of snags and logs was lower in them than in stands at harvest age. The thickness of living oaks and pines was significantly greater than that of their snags and logs, while no differences were found for trembling aspen, silver and downy birch, common hornbeam, common beech and Norway spruce. The distribution of volume across tree species differed between living stands and deadwood. Our results point to the economic value of timber as an important factor determining the distribution, thickness and species composition of deadwood in forest areas.
\end{abstract}

KEY WORDS: deadwood retention, European lowland temperate forest, forest management, Natura 2000

J. Holeksa (autor korespondencyjny), P. Kurek, M. Wojterska, Zakład Ekologii Roślin i Ochrony Środowiska, Wydziat Biologii, Uniwersytet im. Adama Mickiewicza w Poznaniu, ul. Uniwersytetu Poznańskiego 6, 61-614 Poznań,Polska; e-mail: janhol@amu.edu.pl

P. Kapusta, E. Budziakowska-Kubik, L. Piechnik, G. Szarek-Łukaszewska, M. Żywiec, Instytut Botaniki im. W. Szafera Polskiej Akademii Nauk, ul. Lubicz 46, 31-512 Kraków, Polska

K. Izworska, T. Zielonka, Katedra Botaniki, Instytut Biologii, Uniwersytet Pedagogiczny im. Komisji Edukacji Narodowej w Krakowie, ul. Podchorażych 2, 30-084 Kraków, Polska

\section{WSTĘP}

Martwe drewno pełni istotną rolę w ekosystemach leśnych (GUTOWSKI i in. 2004; STOKLAND i in. 2012). Jako źródło materii i energii, a także jako środowisko bytowania organizmów, jest podstawą saproksylicznej sieci pokarmowej, która w warunkach naturalnych stanowi 
znaczącą część biocenozy lasu. Składnikami tej sieci są przede wszystkim grzyby i bezkręgowce, a w dalszej kolejności śluzowce, porosty, rośliny zarodnikowe i kręgowce. W lasach strefy umiarkowanej organizmy te tworzą ugrupowania liczące wiele tysięcy gatunków, mogące stanowić nawet kilkadziesiąt procent ogólnej różnorodności biologicznej. Na bogactwo organizmów saproksylicznych wpływ ma zarówno ilość jak i jakość martwego drewna. Im tego drewna jest więcej i im bardziej jest ono różnorodne (obecne w wielu postaciach - jako posusz stojący, kłody, drobna leżanina, pniaki czy wykroty - i reprezentujące różne gatunki, klasy wielkości oraz stopnie zaawansowania rozkładu), tym szersze jest spektrum mikrosiedlisk wykorzystywanych przez gatunki saproksyliczne, bardziej skomplikowana sieć relacji międzygatunkowych i lepsza kondycja biocenozy leśnej (SIITONEN 2001; STOKLAND i in. 2012; SEIBOLD i in. 2015; GossNer i in. 2016; YlisIRNIÖ i in. 2016).

Badania ostatnich kilku dekad prowadzone na terenie Europy pokazały, że powierzchnia lasów charakteryzujących się zadowalającym stanem zasobów martwego drewna jest bardzo mała, w zasadzie ograniczona do rezerwatów i niewielkich, wyłączonych z gospodarowania fragmentów parków narodowych poddanych ochronie ścisłej, a także do miejsc trudno dostępnych dla człowieka (np. stoków górskich o dużym nachyleniu) (CHRISTENSEN $i$ in. 2005; PASIERBEK $i$ in. 2007). Jest to powierzchnia zbyt mała $i$, pomimo usilnych starań przyrodników, przyrastająca zbyt wolno, aby mogła zagwarantować skuteczną ochronę zespołów saproksylicznych, a tym samym pełną ochronę różnorodności biologicznej ekosystemów leśnych. Wyrazem tego niekorzystnego stanu jest generalnie bardzo mała powierzchnia wszystkich lasów uznanych za naturalne i objętych ochroną, a w szczególności ochroną ścisłą (SABATINI i in. 2018). W obliczu tego faktu za konieczne uznano odbudowę zasobów martwego drewna w części lasów gospodarczych. Urzeczywistnienie tej idei stało się możliwe między innymi dzięki uruchomieniu programu Natura 2000, u podstaw którego stało przekonanie, iż realizacja funkcji użytkowej ekosystemów nie wyklucza prowadzenia działań na rzecz ochrony przyrody. W ramach programu Natura 2000 powstała sieć obszarów chronionych, której obecna powierzchnia znacząco przekracza powierzchnię istniejących rezerwatów i parków narodowych (MAIORANO i in. 2015). Lasy gospodarcze stanowią jej dominujący element, a zwiększenie ilości martwego drewna stało się w nich jednym z priorytetowych celów zabiegów ochronnych.

Sytuacja, w której ochrona przyrody i produkcja drewna są realizowane jednocześnie na tym samym obszarze, prowadzi do konfliktu między korzyściami biologicznymi i ekonomicznymi (RANIUS i in. 2005; JACOBSEN $i$ in. 2013; ANGELSTAM i in. 2018). Z perspektywy ochrony przyrody im więcej jest $\mathrm{w}$ lesie martwego drewna, tym lepsze są $\mathrm{w}$ nim warunki dla sporej grupy organizmów saproksylicznych. Z perspektywy ekonomicznej, zwiększenie ilości martwego drewna oznacza natomiast straty finansowe dla właściciela lasu, ponieważ wymaga od niego powstrzymania się od całkowitej eksploatacji drzewostanów i utrudnia działania gospodarcze. Ponadto tam, gdzie pozostawiane jest martwe drewno, produkcja leśna jest zagrożona przez obecność mikrosiedlisk, stwarzających warunki dla rozwoju niektórych owadów traktowanych jako szkodniki wtórne (SCHROEDER \& LINDELÖW 2002; ERIKSSON i in. 2006; JoHANSSON i in. 2006). Kolejnym problemem jest bezpieczeństwo ludzi. Nieusuwanie zamierających drzew i posuszu stojącego jest korzystne dla niektórych gatunków saproksylicznych, zwiększa jednak ryzyko wypadków podczas prac 
hodowlanych i spacerów po lesie (JАКОВY i in. 2010). Wszystkie te sprzeczne interesy uniemożliwiają utrzymywanie w lasach gospodarczych takiej ilości martwego drewna, jaka znajduje się w rezerwatach leśnych. Dlatego przy odbudowie zasobów martwego drewna w lasach gospodarczych celem jest zazwyczaj osiagnnięcie wartości progowej, tj. pewnego ilościowego minimum, przy którym możliwa jest egzystencja znaczącej części gatunków saproksylicznych, w tym gatunków kluczowych, ważnych dla funkcjonowania ekosystemu. Progi takie zostały już wielokrotnie zaproponowane dla różnych siedlisk leśnych (RANIUS \& FAHrig 2006; Müller \& Bütler 2010; Brunet i in. 2010; StOKLAND i in. 2012).

Efektywne zarządzanie zasobami martwego drewna w wielofunkcyjnych lasach gospodarczych wymaga poznania ich aktualnego stanu oraz zidentyfikowania czynników, które wpływają na ich strukturę ilościowo-jakościową. Wiedzę taka można wykorzystać, aby wzmocnić te praktyki stosowane w gospodarce leśnej, które, mimo że nie są ukierunkowane na ochronę przyrody, tej ochronie sprzyjają, oraz osłabić inne, których efekty są mniej korzystne z punktu widzenia potrzeb gatunków saproksylicznych.

Celem niniejszej pracy było uzyskanie szczegółowych danych na temat zasobów martwego drewna w Puszczy Niepołomickiej - dużym kompleksie leśnym, który został włączony do sieci Natura 2000 w 2004 r., i w którym obok przeważających powierzchniowo lasów gospodarczych znajdują się niewielkie rezerwaty ustanowione w latach 50 . i 60. ubiegłego wieku. Porównana została ilość martwego drewna i jego cechy pomiędzy drzewostanami podlegającymi ochronie rezerwatowej i drzewostanami poddanymi presji gospodarczej. Określone zostały także zależności pomiędzy właściwościami drzewostanów gospodarczych, takimi jak typ siedliskowy, skład gatunkowy, wiek i zasobność, a ilością i jakością drewna wydzielającego się naturalnie, bądź jako efekt uboczny zabiegów hodowlanych. Uzyskane wyniki mogą być pomocne w opracowaniu efektywnej strategii zarządzania zasobami martwego drewna nie tylko w Puszczy Niepołomickiej, ale także na innych obszarach leśnych chronionych w ramach sieci Natura 2000.

\section{MATERIAŁY I METODY}

\section{Teren badań}

Badania przeprowadzono w Puszczy Niepołomickiej, dużym kompleksie leśnym usytuowanym w zachodniej części Kotliny Sandomierskiej (między $49^{\circ} 59^{\prime}$ a $50^{\circ} 07^{\prime}$ szerokości geograficznej północnej i między $20^{\circ} 13^{\prime}$ a $20^{\circ} 28^{\prime}$ długości geograficznej wschodniej), w widłach rzek Wisły i Raby. Kompleks ten dzieli się na dwie części, północną i południową, różniące się wybitnie budową geologiczną, warunkami wilgotnościowymi, rodzajem gleb i typem roślinności. Część północna składa się z trzech uroczysk - Koło, Grobla i Grobelczyk - o łącznej powierzchni nieco ponad 2000 ha. Uroczyska te są położone na terasie zalewowej Wisły, której starorzecza i drobne dopływy przecinają teren leśny gęstą siecią. Na przeważającym obszarze części północnej, na glebach gliniastych, wytworzył się grąd subkontynentalny (Tilio-Carpinetum) (MYCZKOwSKI 1981). Znacznie mniejszą powierzchnię zajmują łęgi i olsy (FERCHMIN 1976; ĆWIKOWA 1981; FeLIKSIK 1981). Część południowa, zwana Uroczyskiem Głównym, znajduje się powyżej granicy terasy zalewowej i obejmuje obszar około 8900 ha. Dominują tu gleby piaszczyste, które porastają głównie drzewostany sosnowe, zaliczane dotąd do zespołu boru mieszanego (Pino-Quercetum) (BEDNARZ 1981; GRUSZCZYK 1981).

Drzewostany Puszczy Niepołomickiej zostały ukształtowane w dużej mierze przez człowieka (GAZDA \& SzLAGa 2008). Naturalne, przeważnie liściaste lasy były w przeszłości mocno eksploatowane 
i z czasem zostały zastąpione drzewostanami odnawianymi sztucznie, z dużym udziałem sosny zwyczajnej (Pinus sylvestris), która pierwotnie była związana z wydmami znajdującymi się w centralnej i południowej części Uroczyska Głównego. Przekształcanie drzewostanów było też rezultatem znacznych zmian warunków siedliskowych, wynikających z trwałego obniżenia poziomu wód gruntowych, którego bezpośrednią przyczyną była budowa rozległego systemu rowów odwadniających. Obecnie podstawowymi gatunkami lasotwórczymi są: sosna zwyczajna (P. sylvestris), dąb szypułkowy (Quercus robur), olsza czarna (Alnus glutinosa) i brzoza brodawkowata (Betula pendula). Na terenie Puszczy Niepołomickiej najbardziej rozpowszechnione są siedliska wilgotne: bór mieszany wilgotny, las mieszany wilgotny i las wilgotny, które łącznie zajmują prawie $70 \%$ jej powierzchni. Lasy siedlisk świeżych obejmują niespełna $25 \%$ powierzchni, a pozostałe kilka procent pokrywają lasy bagienne. Gospodarka leśna oparta jest głównie o odnowienia sztuczne, rębnię gniazdową zupełną - IIIA, rębnię gniazdową częściową - IIIB oraz rębnię zupełną pasową - Ib (BIURo URZĄDZANIA LASU 2011).

Resztki dawnej puszczy przetrwały gdzieniegdzie w postaci niewielkich ostoi leśnych lub też okazałych, wiekowych drzew. Po II Wojnie Światowej niektórym starym drzewostanom nadano status rezerwatów przyrody. Jest ich pięć: „Dębina” (12,66 ha; powołany 24.12.1957 r., podlega ochronie ścisłej), „Długosz Królewski” (24,14 ha; powołany 26.04.1963 r., podlega ochronie częściowej), „Gibiel” (28,89 ha; powołany 21.10.1961 r., podlega ochronie częściowej), „Lipówka” (25,73 ha; powołany 24.12.1957 r., podlega ochronie ścisłej) i „Koło” (3,49 ha; powołany 21.04.1962 r., podlega ochronie częściowej). W Puszczy Niepołomickiej znajdują się także powierzchnie reprezentatywne dla siedlisk leśnych, tzw. powierzchnie referencyjne, zajmujące łącznie obszar 284 ha, na których nie prowadzi się zabiegów gospodarczych. Puszcza Niepołomicka jest w całości Obszarem Specjalnej Ochrony Ptaków (PLB120002), a niektóre jej fragmenty zostały uznane za obszary specjalnej ochrony siedlisk: Koło Grobli (PLH120008; 597,85 ha), Lipówka (PLH120010; 25,73 ha) i Torfowisko Wielkie Błoto (PLH120080; o powierzchni 108,68 ha). Wszystkie zostały ustanowione Rozporządzeniem Ministra Ochrony Środowiska z dnia 21.07.2004 r. Wcześniej, w latach 90. XX w., Puszcza uzyskała status Leśnego Kompleksu Promocyjnego.

\section{Powierzchnie badawcze oraz pomiar żywych i martwych drzew}

Pomiary żywych i martwych drzew prowadzono na 187 powierzchniach badawczych, pokrywających równomiernie cały teren Puszczy Niepołomickiej (Ryc. 1). Zlokalizowane zostały zarówno w lasach gospodarczych $(\mathrm{N}=183)$ jak i rezerwatach przyrody $(\mathrm{N}=4)$. Powierzchnie zakładano w co drugim oddziale leśnym (w geometrycznym środku oddziału), posługując się przygotowaną wcześniej mapą elektroniczną i odbiornikiem GPS. W kilku przypadkach konieczne było przesunięcie powierzchni w celu ominięcia drogi lub innego rodzaju przeszkód terenowych. Powierzchnie miały kształt prostokąta o wymiarach $20 \mathrm{~m} \times 200 \mathrm{~m}$ (0,4 ha). Orientację jego dłuższego boku każdorazowo losowano spośród dwóch kierunków N-S i E-W, żeby zredukować błąd systematyczny pomiarów. Powierzchnie badawcze łącznie objęły obszar 74,8 ha.

Na każdej powierzchni zmierzono grubość każdego drzewa na wysokości 1,3 m (pierśnicę). Z pomiarów wyłączono osobniki o grubości mniejszej niż $10 \mathrm{~cm}$. Dla pospolitych gatunków drzew mierzono wysokości 100-400 żywych osobników, starając się, by reprezentowany był cały zakres zmienności pierśnic i pełne spektrum warunków siedliskowych. W przypadku rzadkich gatunków drzew mierzono wysokości wszystkich osobników. Po wyznaczeniu za pomocą tabel (CzURAJ 1991) miąższości żywych drzew, uzyskano dla każdego gatunku krzywą miąższości. Dla sosny i dębów sporządzono dwie krzywe miąższości - jedną dla siedlisk lasowych, a drugą dla borowych. Otrzymane równania krzywych miąższości wykorzystano do obliczenia miąższości wszystkich drzew zmierzonych na powierzchniach badawczych.

W badaniach uwzględniono trzy frakcje martwego drewna: posusz stojący (martwe stojące drzewa i złomy o wysokości równej lub większej niż 1,3 m), posusz leżący (powalone drzewa, kłody i grube gałęzie o długości co najmniej $1 \mathrm{~m}$ ) oraz pniaki (o wysokości poniżej 1,3 m). Pomiarami objęto wszystkie martwe drzewa i ich fragmenty o grubości co najmniej $10 \mathrm{~cm}$ na grubszym końcu (kłody) lub u podstawy (na wysokości pierśnicy w przypadku posuszu stojącego i w połowie wysokości w przypadku pniaków). W przypadku posuszu stojącego oprócz pierśnicy mierzono wysokość oraz szacowano średnicę 


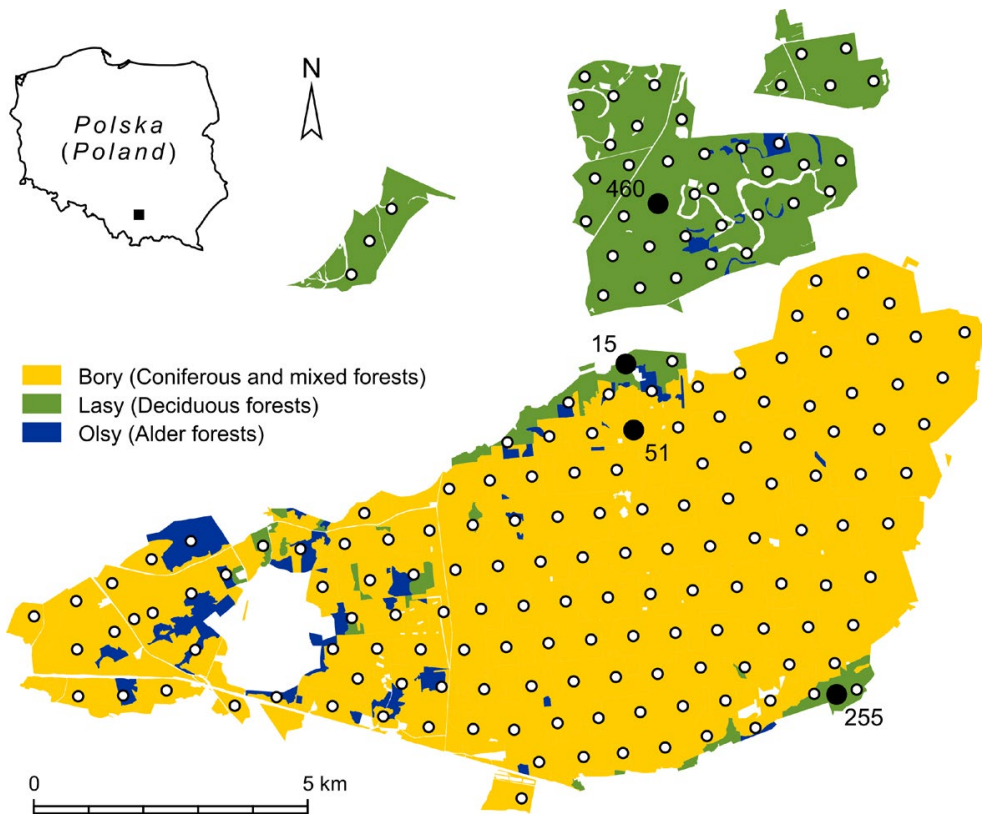

Ryc. 1. Rozmieszczenie 187 powierzchni badawczych na terenie Puszczy Niepołomickiej. Powierzchnie w drzewostanach gospodarczych oznaczono małymi białymi kółkami; powierzchnie w rezerwatach oznaczono dużymi czarnymi kółkami (obok nich umieszczono numery oddziałów leśnych)

Fig. 1. Location of 187 study sites in the Niepołomice Forest. White dots indicate study sites in managed stands; larger black dots indicate study sites in nature reserves (next to them are forest division numbers)

w szczytowym punkcie, jeśli posusz był pozbawiony wierzchołka. W przypadku posuszu leżącego mierzono długość i średnice na obu końcach. Pomiary pniaków obejmowały wysokość i grubość w połowie wysokości.

Miąższość posuszu stojącego i leżącego obliczono ze wzoru na objętość stożka ściętego. W przypadku posuszu stojącego do wzoru podstawiono średnicę u podstawy pnia wyznaczoną za pomocą twierdzenia Talesa. Objętość pniaków obliczono ze wzoru na objętość walca, przy czym za jego średnicę przyjęto grubość w połowie wysokości. Każde martwe drzewo lub jego fragment identyfikowano do gatunku i oceniano pod względem stopnia zaawansowania rozkładu według pięciostopniowej skali, w której stopnie 1 i 5 oznaczają odpowiednio drewno najmniej i najbardziej rozłożone (MASER i in. 1988). Na podstawie zebranych danych, dla każdej powierzchni policzono całkowitą objętość martwego drewna, jego różnorodność taksonomiczną oraz średni stopień rozkładu.

Z powodu trudności w identyfikacji martwych szczątków drzew w tracie pomiarów terenowych nie rozróżniano niektórych blisko spokrewnionych ze sobą gatunków, np. brzozy brodawkowatej od omszonej, dębu szypułkowego od bezszypułkowego i wiązu górskiego od szypułkowego. Takie gatunki łączono i traktowano w analizach jak jeden takson (dotyczyło to także żywych drzew). Dlatego w dalszej części piszemy o taksonach, a nie o gatunkach drzew.

\section{Analiza danych}

Na podstawie informacji zawartych w Planie Urządzenia Lasów dla nadleśnictwa Niepołomice na lata 2012-2021 (BIURO URZĄDZANIA LASU 2011), każdą powierzchnię zaliczono do jednej z sześciu klas wieku drzewostanu: I - do 20 lat, II - 21-40 lat, III - 41-60 lat, IV - 61-80 lat, V - 81-100 lat i VI - powyżej 100 lat. Klasy I i II połączono (klasa I-II) z uwagi na małą liczbę reprezentujących je 
powierzchni. Powierzchnie przyporządkowano także do jednej z trzech grup siedliskowych: 1) bory i bory mieszane na siedliskach świeżych i wilgotnych, 2) lasy i lasy mieszane na siedliskach świeżych i wilgotnych oraz 3 ) olsy i olsy jesionowe. W dalszej części artykułu dla tych trzech grup używane są nazwy: bory, lasy i olsy. Jeśli powierzchnia przecinała wydzielenia leśne z różnymi typami siedliskowymi lasu i różnymi drzewostanami, zaliczano ja do grupy siedliskowej lub klasy wieku dominującej powierzchniowo.

Różnice w cechach drzewostanów oraz w ilości i jakości martwego drewna pomiędzy poszczególnymi klasami wieku drzewostanu i typami siedliskowymi lasu określono przy użyciu testu Tukeya (testu wielokrotnych porównań), poprzedzonego jednoczynnikową analizą wariancji (ANOVA). Przed analizą statystyczną zmienne o rozkładach skośnych transformowano (najczęściej przy użyciu funkcji logarytmicznej), aby uzyskać rozkład normalny lub przynajmniej symetryczny. Analizę przeprowadzono z wykorzystaniem programu Past 3.0 (HAMMER i in. 2001).

\section{WYNIKI}

\section{Drzewostany}

Zasobność (miąższość) drzewostanów w części gospodarczej Puszczy Niepołomickiej wahała się od 18 do $561 \mathrm{~m}^{3} \mathrm{ha}^{-1}$ (średnio $282 \mathrm{~m}^{3} \mathrm{ha}^{-1}$ ). Zasobność ta była istotnie wyższa w drzewostanach lasów niż w drzewostanach borów i olsów ( $F=7,3 ; p<0,001 ;$ Ryc. 2a). W rezerwatach chroniących grądy („Gibiel 1” - oddział 15, „Gibiel 2” - oddział 51, „Dębina” - oddział 255 oraz „Lipówka” - oddział 460) miąższoóć drzewostanów wynosiła odpowiednio: 360, 446, 479 i $644 \mathrm{~m}^{3} \mathrm{ha}^{-1}$. Zasobność drzewostanów gospodarczych była ściśle związana $\mathrm{z}$ ich wiekiem $(F=62,4 ; p<0,001$; Ryc. $2 \mathrm{~b})$. Najniższą zasobnością cechowały się drzewostany w wieku do 40 lat, a najwyższą - drzewostany ponad stuletnie.

Liczba taksonów drzew występujących na poszczególnych powierzchniach badawczych wahała się od 2 do 12 (średnio wynosiła 5,8). W olsach i lasach liczba ta była większa niż w borach; różnica, chociaż niewielka, była istotna statystycznie $(F=5,3 ; p<0,01 ;$ Ryc. $2 \mathrm{c})$. Liczba taksonów drzew różniła się istotnie także pomiędzy poszczególnymi klasami wieku drzewostanu ( $F=7,1 ; p<0,001$; Ryc. 2 d). Najwięcej taksonów było w drzewostanach młodych, w wieku do 40 lat i w wieku 41-60 lat, a najmniej w drzewostanach najstarszych, w wieku 81-100 lat i ponad stuletnich.

Panującym gatunkiem drzewa była sosna, której udział w miąższości drzewostanów wynosił 45\% (Ryc. 3a). Prawie dwukrotnie mniejszy udział (24\%) miały rodzime dęby. Trzecim gatunkiem pod względem udziału miąższościowego była olcha czarna $-11 \%$. Wśród pozostałych taksonów, z więcej niż jednoprocentowym udziałem w miąższości, najwięcej było: brzóz, grabu, lipy i modrzewia (Ryc. 3b).

W drzewostanach gospodarczych średnia pierśnica drzew wynosiła $25 \mathrm{~cm}$ (w obliczeniach nie uwzględniano osobników o pierśnicy < $10 \mathrm{~cm}$; patrz MATERIAŁY I METODY). Przeszło dwie trzecie drzew nie przekraczało grubości $30 \mathrm{~cm}$. Grubość $50 \mathrm{~cm}$ i większą miało tylko 3,2\% populacji - takich osobników było średnio 14 na jednym hektarze. $\mathrm{W}$ rezerwatach przeciętna grubość drzew wynosiła $31 \mathrm{~cm}$. Nieco ponad jedna trzecia drzew nie przekraczała grubości $30 \mathrm{~cm}$, a ponad półmetrową grubością cechowało się $11 \%$ drzew - 37 na jednym hektarze. 
a)

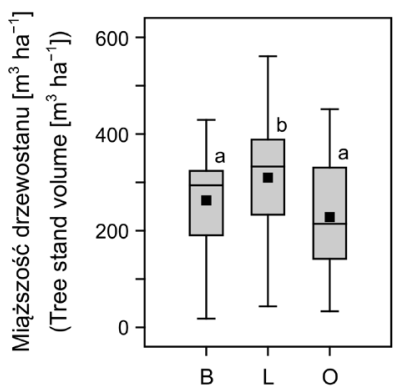

c)

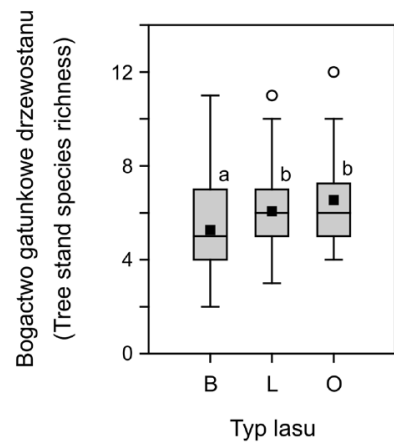

(Type of forest) b)

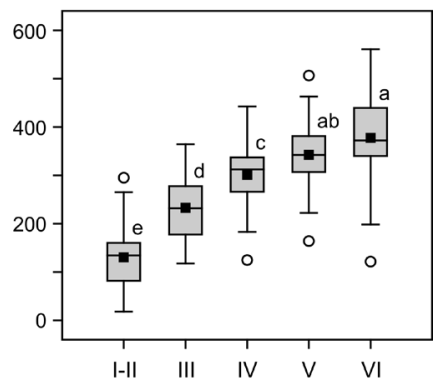

d)

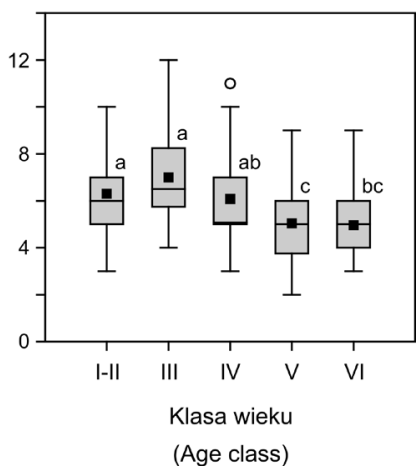

Ryc. 2. Miąższość drzewostanu w przeliczeniu na hektar (a, b) oraz liczba gatunków drzew odnotowana na powierzchni badawczej (c, d) według typu siedlisk (a, c) i klasy wieku (b, d). Typy siedlisk: B - bory, L - lasy, O - olsy. Klasy wieku: I-II - do 40 lat, III - 41-60 lat, IV - 61-80 lat, V - 81-100 lat, VI - powyżej 100 lat. Typy siedlisk lub klasy wieku różnią się od siebie w sposób istotny statystycznie, jeśli zostały oznaczone różnymi literami (test Tukeya; $p<0,05$ ). Wykresy pudełkowe przedstawiają medianę (pozioma linia) i średnią (czarny kwadrat), pierwszy i trzeci kwartyl, wartość mimalną i maksymalną oraz wartości odstające

Fig. 2. Tree stand volume per hectare $(a, b)$ and number of tree species per study plot (c, d) by forest type (a, c) and age class (b, d). Forest types: B - coniferous and mixed, L - deciduous, O - alder. Age classes: I-II - up to 40 years, III - 41-60 years, IV - 61-80 years, V - 81-100 years, VI - more than 100 years. Forest types and age classes bearing different letters differ significantly from each other (by Tukey's test; $p<0.05$ ). Box plots represent median (horizontal line) and mean (black square), first and third quartiles, minimum and maximum values, and outliers

\section{Martwe drewno}

Parametry ilościowe i jakościowe martwego drewna z podziałem na trzy frakcje - posusz stojący, posusz leżący i pniaki - zostały przedstawione w tabeli 1 .

Zagęszczenie elementów martwego drewna w lasach gospodarczych wynosiło od 45 to 478 (średnio 184) sztuk ha ${ }^{-1}$, przy czym posuszu leżącego było przeciętnie niemal trzy razy więcej niż posuszu stojącego, odpowiednio 38 i 14 sztuk ha $^{-1}$, natomiast pniaków było dwa i pół razy więcej niż posuszu stojącego i leżącego razem - 132 sztuk ha-1 ${ }^{-1}$ Typy siedliskowe lasów nie różniły się między sobą w sposób istotny statystycznie, jeśli chodzi o zagęszczenie pniaków (Ryc. 4c), natomiast różniły się pod względem zagęszczenia posuszu stojącego $(F=4,5 ; p<0,05)$ i leżącego $(F=4,3 ; p<0,05)$. W obu przypadkach większe zagęszczenie posuszu było w olsach niż w borach i lasach (Ryc. $4 \mathrm{a}, \mathrm{b}$ ). Drzewostany 

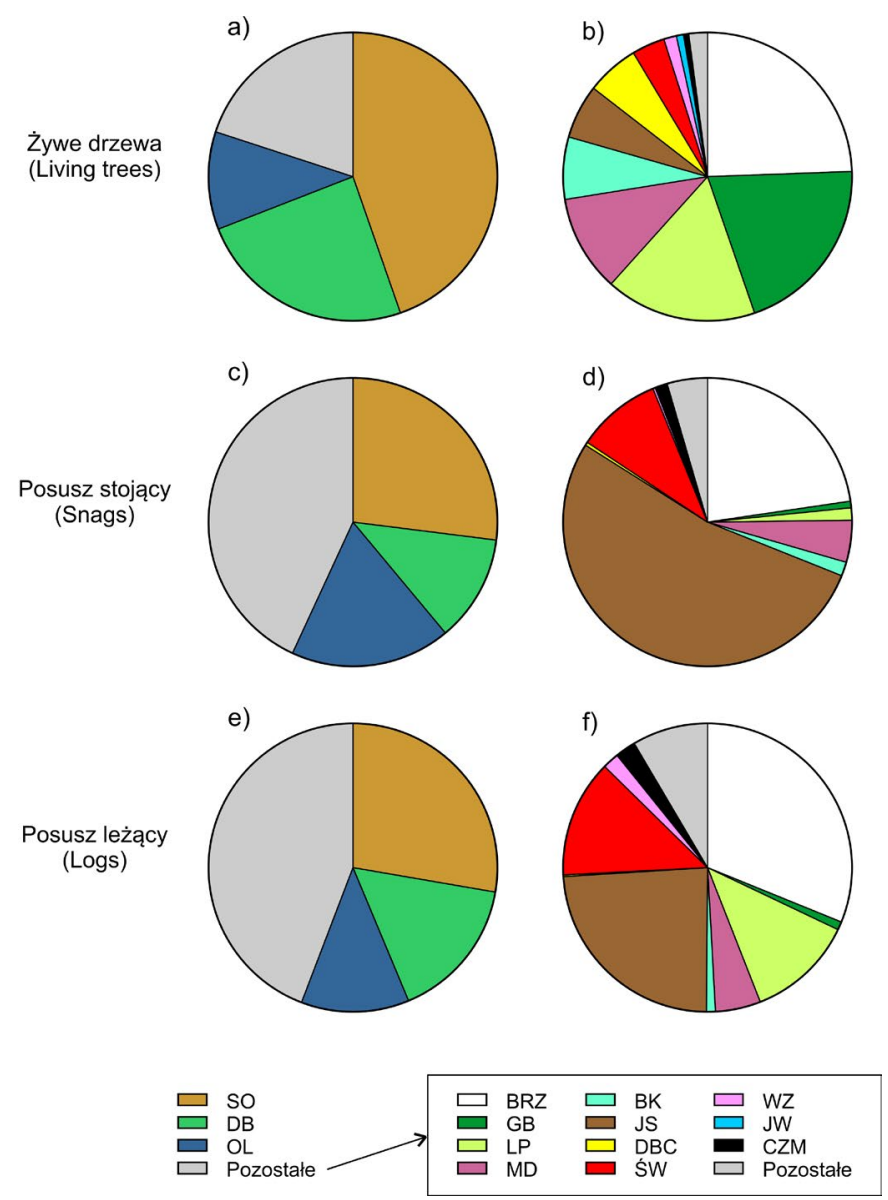

Ryc. 3. Udział poszczególnych gatunków drzew w całkowitej miąższości żywych drzew, posuszu stojącego i posuszu leżącego pokazany osobno dla gatunków dominujących (a, c, e) i gatunków towarzyszących (b, d, f). Oznaczenia gatunków: SO - sosna, DB - dąb, OL - olcha, BRZ - brzoza, GB - grab, LP - lipa, MD - modrzew, BK - buk, JS - jesion, DBC - dąb czerwony, ŚW - świerk, WZ - wiąz, JW - jawor, CZM - czeremcha

Fig. 3. Shares of individual tree species in the total volume of living trees, snags and logs, shown separately for dominant species (a, c, e) and accompanying species (b, d, f). Species labels: SO - pine, DB - oak, OL - alder, BRZ - birch, GB - hornbeam, LP - lime, MD - larch, BK - beech, JS - ash, DBC - red oak, ŚW - spruce, WZ - elm, JW - sycamore, CZM - bird cherry, Pozostałe - others

różnych klas wieku, odwrotnie, nie różniły się zagęszczeniem posuszu (stojącego i leżącego), ale różniły się zagęszczeniem pniaków $(F=19,8 ; p<0,001)$ - było ono większe w młodszych drzewostanach (Ryc. 5a).

W rezerwatach chroniących lasy grądowe zagęszczenie martwego drewna zawierało się w przedziale 129-270 sztuk ha ${ }^{-1}$, wynosząc średnio 182 sztuki ha $^{-1}$ (Tab. 1). Podczas gdy w drzewostanach gospodarczych dominowały pniaki, w rezerwatach przeważał liczebnie posusz leżący - było go około 7 razy więcej niż posuszu stojącego i około 3 razy więcej niż pniaków.

Miąższość martwego drewna w drzewostanach gospodarczych wahała się od 1,5 do $67,6 \mathrm{~m}^{3} \mathrm{ha}^{-1}$, wynosząc średnio $9,2 \mathrm{~m}^{3} \mathrm{ha}^{-1}$. Miąższości posuszu stojącego, posuszu 
Tabela 1. Zagęszczenie (sztuk ha $\left.{ }^{-1}\right)$, miąższość $\left(\mathrm{m}^{3} \mathrm{ha}^{-1}\right)$, stopień rozkładu oraz bogactwo gatunkowe (liczba gatunków na powierzchni o wielkości 0,4 ha) martwego drewna określone dla 187 powierzchni badawczych założonych w drzewostanach gospodarczych $(\mathrm{N}=183)$ i wybranych rezerwatach $(\mathrm{N}=4)$ Puszczy Niepołomickiej

Table 1. Density (pieces ha ${ }^{-1}$ ), volume $\left(\mathrm{m}^{3} \mathrm{ha}^{-1}\right)$, stage of decay and species richness (number of species per 0.4 ha) of deadwood determined for 187 study plots established in managed stands $(\mathrm{N}=183)$ and selected nature reserves $(\mathrm{N}=4)$ of the Niepołomice Forest

\begin{tabular}{|c|c|c|c|c|c|c|c|c|}
\hline \multirow{2}{*}{$\begin{array}{l}\text { Parametr } \\
\text { (Parameter) }\end{array}$} & \multirow{2}{*}{$\begin{array}{c}\text { Kategoria } \\
\text { martwego drewna } \\
\text { (Deadwood type) }\end{array}$} & \multicolumn{3}{|c|}{$\begin{array}{l}\text { Drzewostany gospodarcze } \\
\text { (Managed stands) }\end{array}$} & \multicolumn{4}{|c|}{$\begin{array}{l}\text { Rezerwaty } \\
\text { (Reserves) }\end{array}$} \\
\hline & & $\begin{array}{l}\text { Mediana } \\
\text { (Median) }\end{array}$ & $\begin{array}{l}\text { Średnia }(\mathrm{OS})^{1} \\
\text { Mean }(\mathrm{SD})^{1}\end{array}$ & $\begin{array}{l}\text { Zakres } \\
\text { (Range) }\end{array}$ & $\begin{array}{l}\text { Gibiel } 1 \\
\mathrm{Nr} 15 \\
(\text { No. } 15)\end{array}$ & $\begin{array}{l}\text { Gibiel } 2 \\
\text { Nr } 51 \\
(\text { No. } 51)\end{array}$ & $\begin{array}{c}\text { Dębina } \\
\text { Nr 255 } \\
\text { (No. 255) }\end{array}$ & $\begin{array}{l}\text { Lipówka } \\
\text { Nr } 460 \\
\text { (No. 460) }\end{array}$ \\
\hline \multirow[t]{3}{*}{$\begin{array}{l}\text { Zagęszczenie } \\
\text { (Density) }\end{array}$} & $\begin{array}{l}\text { Posusz stojący } \\
\text { (Snags) }\end{array}$ & 8 & $14(17)$ & $0-110$ & 18 & 10 & 35 & 10 \\
\hline & $\begin{array}{l}\text { Posusz leżący } \\
(\operatorname{Logs})\end{array}$ & 33 & $38(29)$ & $0-143$ & 73 & 50 & 113 & 255 \\
\hline & Pniaki (Stumps) & 110 & $132(87)$ & $8-425$ & 38 & 83 & 38 & 5 \\
\hline \multirow[t]{3}{*}{$\begin{array}{l}\text { Miąższość } \\
\text { (Volume) }\end{array}$} & $\begin{array}{l}\text { Posusz stojący } \\
\text { (Snags) }\end{array}$ & 2,0 & $3,4(5,7)$ & $0-57,3$ & 12,3 & 9,6 & 10,1 & 8,1 \\
\hline & $\begin{array}{l}\text { Posusz leżący } \\
(\operatorname{Logs})\end{array}$ & 2,3 & $3,5(4,1)$ & $0-25,7$ & 3,2 & 36,6 & 27,3 & 158,7 \\
\hline & Pniaki (Stumps) & 1,9 & $2,3(1,6)$ & $0,3-13,7$ & 4,3 & 2,2 & 4,5 & 0,3 \\
\hline \multirow{3}{*}{$\begin{array}{l}\text { Stopień } \\
\text { rozkładu } \\
\text { (Decay stage) }\end{array}$} & $\begin{array}{l}\text { Posusz stojący } \\
\text { (Snags) }\end{array}$ & 1,5 & $1,6(0,5)$ & $1,0-4,0$ & 1,0 & 2,5 & 1,9 & 2,5 \\
\hline & $\begin{array}{l}\text { Posusz leżący } \\
\text { (Logs) }\end{array}$ & 2,3 & $2,3(0,6)$ & $1,0-4,0$ & 2,0 & 2,3 & 2,5 & 3,1 \\
\hline & Pniaki (Stumps) & 3,2 & $3,2(0,5)$ & $1,3-4,4$ & 2,7 & 3,5 & 2,5 & 4,5 \\
\hline \multirow{3}{*}{$\begin{array}{l}\text { Bogactwo } \\
\text { gatunków } \\
\text { (Species } \\
\text { richness) }\end{array}$} & $\begin{array}{l}\text { Posusz stojący } \\
\text { (Snags) }\end{array}$ & 2 & $1,8(1,2)$ & $0-6$ & 4 & 3 & 4 & 3 \\
\hline & $\begin{array}{l}\text { Posusz leżący } \\
\text { (Logs) }\end{array}$ & 3 & $2,8(1,4)$ & $0-7$ & 4 & 4 & 3 & 3 \\
\hline & Pniaki (Stumps) & 3 & $3,4(1,4)$ & $1-7$ & 3 & 3 & 3 & 2 \\
\hline
\end{tabular}

${ }^{1}$ OS (SD) - odchylenie standardowe (standard deviation).

leżącego i pniaków pozostawały względem siebie w proporcji, w przybliżeniu, 3:3:2 (Tab. 1). Typy siedliskowe lasu nie różniły się między sobą jeżeli chodzi o miąższość posuszu stojącego (Ryc. 4d), różniły się natomiast miąższością posuszu leżącego (olsy przewyższały pod tym względem bory i lasy; $F=4,5$; $p<0,05$; Ryc. 4e) i miąższością pniaków (miąższość pniaków w borach była niższa niż w lasach; $F=4,3 ; p<0,05$; Ryc. 4f). Różnice w miąższości martwego drewna pomiędzy klasami wieku były podobne jak te opisane dla zagęszczenia - dotyczyły tylko pniaków, których miąższościowo było najwięcej w najmłodszych drzewostanach, a najmniej w drzewostanach dojrzałych, IV i V $(F=9,9 ; p<0,001)$. W rezerwatach miąższość martwego drewna wahała się od 20 do $167 \mathrm{~m}^{3} \mathrm{ha}^{-1}$ (Tab. 1).

Liczba taksonów reprezentowanych w puli martwego drewna, występującego na poszczególnych powierzchniach badawczych wahała się od 1 do 9 (średnio 4,1). Największym bogactwem taksonomicznym charakteryzowały się pniaki, a najmniejszym posusz stojący 
(Tab. 1). Bogactwo taksonomiczne martwego drewna było istotnie związane z typem siedliska - najmniej taksonów notowano w borach, a najwięcej w olsach; wzorzec ten był najlepiej widoczny w przypadku posuszu leżącego $(F=11,8 ; p<0,001$; wszystkie typy siedlisk różniły się od siebie nawzajem w sposób istotny statystycznie; Ryc. 5b). Bogactwo taksonomiczne martwego drewna było słabo zależne od wieku; jedyne statystycznie istotne różnice odnotowano dla pniaków $(F=5,2 ; p<0,001)$; w młodszych drzewostanach (I-II i III) liczba taksonów pniaków było nieco wyższa (średnio o 1) niż w drzewostanach starszych (IV, V i VI).

Grubość stojącego posuszu w drzewostanach gospodarczych wynosiła średnio $19 \mathrm{~cm}$. Zdecydowana większość tego posuszu (aż 86\%) była cieńsza niż $30 \mathrm{~cm}$, a tylko 1,9\% osiągało lub przekraczało grubość $50 \mathrm{~cm}$ (Ryc. 6). Przeciętnie jedno martwe stojące drzewo (lub złom), o co najmniej półmetrowej grubości przypadało na 3,9 ha lasu. W rezerwatach

a)

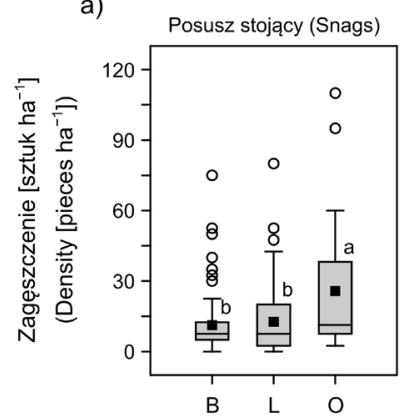

d)

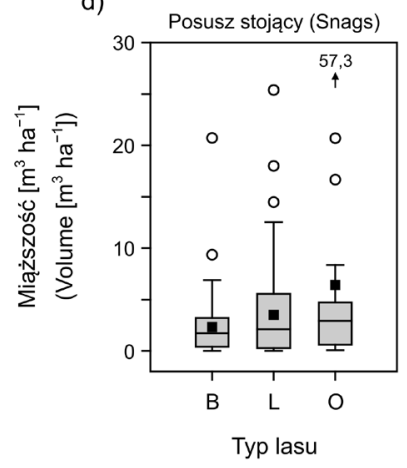

(Type of forest) b)

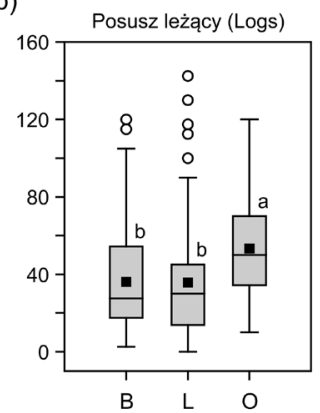

e)

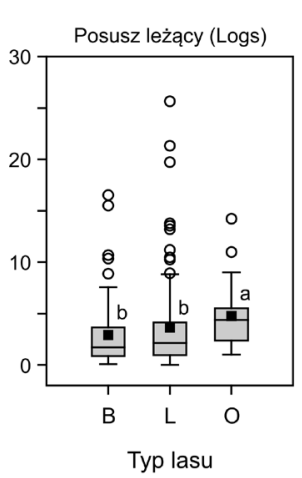

(Type of forest) c)

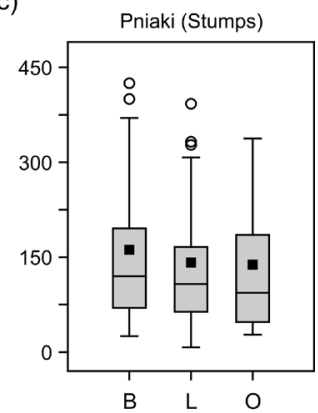

f)

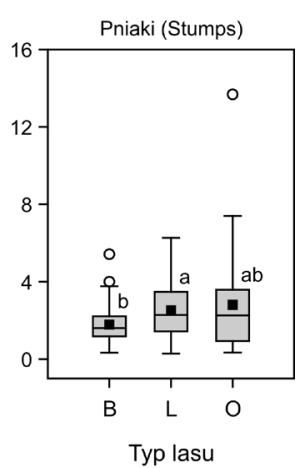

(Type of forest)

Ryc. 4. Zagęszczenie (a-c) i miąższość (d-f) martwego drewna z podziałem na 3 frakcje - posusz stojący (a, d), posusz leżący (b, e) i pniaki (c, f) - i według typu siedlisk (B - bory, L - lasy, O - olsy). Typy siedlisk różnią się od siebie w sposób istotny statystycznie, jeśli zostały oznaczone różnymi literami (test Tukeya; $p<0,05$ ). Uwaga: dla poprawienia czytelności wyników z wykresu miąższości posuszu stojącego w olsach (d) usunięto jedną wartość odstająca (57,3). Wykresy pudełkowe przedstawiają medianę (pozioma linia) i średnią (czarny kwadrat), pierwszy i trzeci kwartyl, wartość mimalną i maksymalną oraz wartości odstające

Fig. 4. Density (a-c) and volume (d-f) of deadwood, shown separately for three categories: snags (a, d), $\operatorname{logs}(b, e)$ and stumps (c, f); and by forest type (B - coniferous and mixed, $\mathrm{L}-$ deciduous, $\mathrm{O}-$ alder). Forest types and age classes bearing different letters differ significantly from each other (by Tukey's test; $p<0.05$ ). For clarity of results, one outlier (57.3) was removed from the box plot of snag volume in alder forests (d). Box plots represent the median (horizontal line) and mean (black square), first and third quartiles, minimum and maximum values, and outliers 

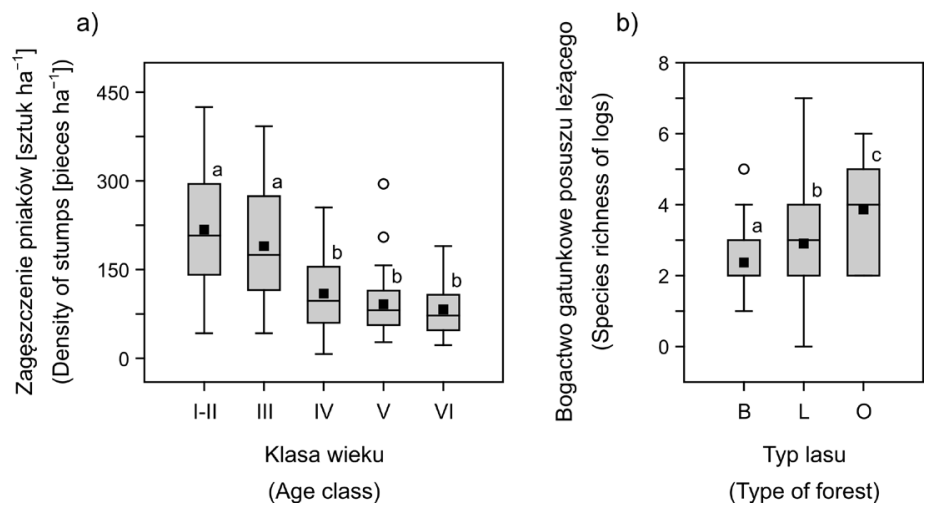

Ryc. 5. Zagęszczenie pniaków (a) w poszczególnych klasach wieku (I-II - do 40 lat, III - 41-60 lat, IV - 61-80 lat, V - 81-100 lat, VI - powyżej 100 lat) oraz bogactwo gatunkowe posuszu leżącego (b) według typu lasu (B - bory, L - lasy, O - olsy). Typy siedlisk lub klasy wieku różnią się od siebie w sposób istotny statystycznie, jeśli zostały oznaczone różnymi literami (test Tukeya; $p<0,05$ ). Wykresy pudełkowe przedstawiają medianę (pozioma linia) i średnią (czarny kwadrat), pierwszy i trzeci kwartyl, wartość mimalną i maksymalną oraz wartości odstające

Fig. 5. Stump density (a) by age class (I-II - up to 40 years, III - 41-60 years, IV - 61-80 years, V - 81-100 years, $\mathrm{VI}$ - more than 100 years) and species richness of logs (b) by forest type (B - coniferous and mixed, $\mathrm{L}-\mathrm{deciduous,}$ $\mathrm{O}$ - alder). Forest types and age classes bearing different letters differ significantly from each other (by Tukey's test; $p<0.05$ ). Box plots represent the median (horizontal line) and mean (black square), first and third quartiles, minimum and maximum values, and outliers

średnia pierśnica stojącego posuszu wynosiła $26 \mathrm{~cm}$. Tak jak w drzewostanach gospodarczych dominowały tu pnie o grubości poniżej $30 \mathrm{~cm}$ (76\%). Tych najgrubszych, o pierśnicy równej lub przekraczającej pół metra było stosunkowo dużo (14\%); na jednym hektarze znajdowano przeciętnie 2,5 sztuki.

Średnia grubość posuszu leżącego (mierzona przy grubszym końcu) w drzewostanach gospodarczych wynosiła $16 \mathrm{~cm}$, przy czym $95 \%$ tego posuszu była cieńsza niż $30 \mathrm{~cm}$, a tylko $0,5 \%$ osiaggało lub przekraczało grubość $50 \mathrm{~cm}$ (Ryc. 6). Średnio jedno leżące drzewo (lub jego fragment) o grubości równej lub przekraczającej 0,5 m przypadało na około 5,6 ha lasu. W rezerwatach przeciętna grubość posuszu leżącego wynosiła $24 \mathrm{~cm}$. Posusz o grubości poniżej $30 \mathrm{~cm}$ stanowił 77\%, a ten o grubości ponad półmetrowej - 12\%; na jednym hektarze lasu chronionego tego ostatniego było przeciętnie 14 sztuk.

Grubość stojącego i leżącego posuszu różniła się znacznie między taksonami. Największa była w przypadku osiki i jesionu (średnio 26 i $20 \mathrm{~cm}$ ), nieco mniejsza w przypadku brzóz (19 cm). Posusz o najmniejszej grubości (średnio poniżej $15 \mathrm{~cm}$ ) należał do czeremchy, grabu, świerka, jarzębiny i buka (w obliczeniach nie uwzględniano gatunków występujących incydentalnie, tj. odnotowanych mniej niż 20 razy na wszystkich powierzchniach).

Udział (miąższościowy) poszczególnych taksonów w puli posuszu stojącego i leżącego różnił się znacznie. Największy udział miała sosna - 27\%. Drewna jesionowego było 17\%, a olchowego, dębowego i brzozowego odpowiednio 15\%, 14\% i 12\%. Wśród pozostałych gatunków ponad jednoprocentowy udział w miąższości posuszu osiągnęły jeszcze: świerk, lipa, modrzew i osika. Posusz stojący różnił się od posuszu leżącego pod względem struktury taksonomicznej. Ten pierwszy charakteryzował się większym udziałem olszy czarnej i jesionu oraz mniejszym udziałem dębów i brzóz niż ten drugi (Ryc. 3c-f). 


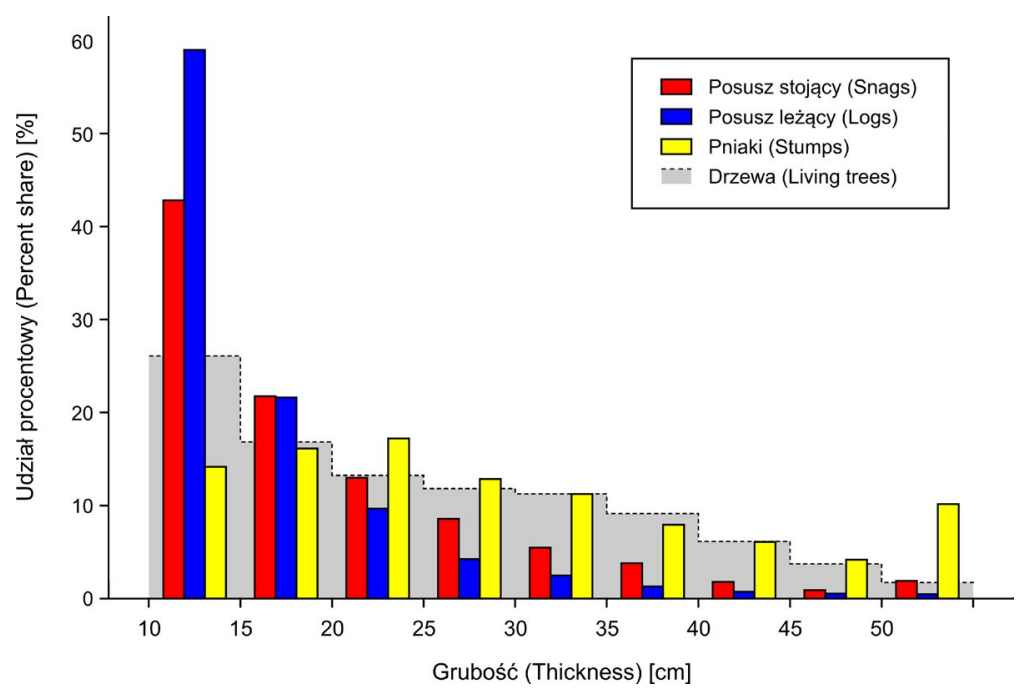

Ryc. 6. Rozkład grubości martwego drewna (słupki) i żywych drzew (wykres schodkowy). Ostatnia klasa grubości obejmuje wszystkie pomiary od $50 \mathrm{~cm}$ wzwyż

Fig. 6. Diameter distribution of deadwood (bars) and living trees (step chart). The last thickness class includes all measurements equal to or larger than $50 \mathrm{~cm}$

a)

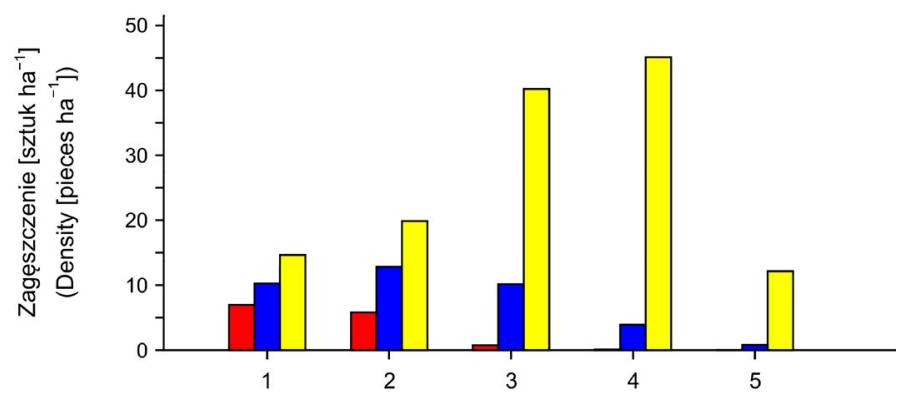

b)

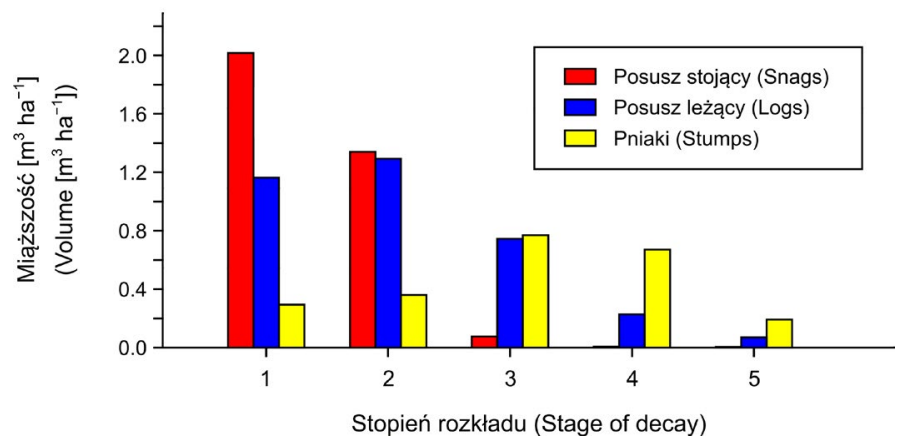

Ryc. 7. Liczebność (a) i miąższość (b) martwego drewna według stopnia zaawansowania rozkładu: od najmniej rozłożonego (1) do najbardziej rozłożonego (5)

Fig. 7. Number (a) and volume (b) of deadwood by decay stage, from least decayed (1) to most decayed (5) 
Średni stopień rozkładu był różny w poszczególnych frakcjach martwego drewna (Tab. 1). W drzewostanach gospodarczych najniższą wartość odnotowano dla posuszu stojącego $(1,6)$, pośrednią dla posuszu leżącego $(2,3)$, a najwyższą dla pniaków $(3,2)$. W rezerwatach wzorzec był podobny, ale średni stopień rozkładu był nieco wyższy; wynosił odpowiednio 2,0, 2,5 i 3,3 dla posuszu stojącego, posuszu leżącego i pniaków.

Poszczególne stopnie rozkładu były nierównomiernie reprezentowane. W przypadku posuszu stojącego dominowały stopnie 1 i 2 , natomiast stopnie 4 i 5 były prawie nieobecne (Ryc. 7a). W przypadku posuszu leżącego dominował stopnień 2, który liczebnościowo tylko trochę przewyższał stopnie 1 i 3 . Frekwencja posuszu leżącego w stopniach 4 i 5 była zdecydowanie wyższa niż posuszu stojącego, ale wciąż niska w porównaniu z niższymi stopniami rozkładu (Ryc. 7a). W przeciwieństwie do posuszu stojącego i leżącego, pniaki należały w większości do wyższych stopni rozkładu, głównie do stopnia 3 i 4 (Ryc. 7a). We wszystkich stopniach rozkładu pniaki były liczniejsze od posuszu stojącego i leżącego; ta przewaga powiększała się wraz ze wzrostem stopnia rozkładu. Miąższościowo pniaki dominowały nad pozostałymi frakcjami martwego drewna tylko w dwóch ostatnich stopniach rozkładu (Ryc. 7b). Taksony najliczniej reprezentowane w Puszczy Niepołomickiej - sosna, dęby i olsza - nie różniły się istotnie między sobą pod względem udziału martwego drewna w poszczególnych stopniach rozkładu.

Średnie wartości stopnia rozkładu martwego drewna nie różniły się między borami, lasami i olsami. Zanotowano natomiast statystycznie istotne różnice pomiędzy klasami wieku. Dotyczyły one tylko posuszu leżącego $(F=5,0 ; p<0,001)$, który był słabiej rozłożony w najmłodszych drzewostanach (do 40 lat) w porównaniu z drzewostanami starszymi (w wieku 41-60, 61-80 i 81-100 lat).

\section{Cechy drzewostanów a zasoby martwego drewna}

Udział martwego drewna w całkowitej miąższości drewna (zsumowanej miąższości martwych i żywych drzew) w Puszczy Niepołomickiej wahał się od 0,4 do 47\% (średnio 4,1\%). W olsach był on wyraźnie większy niż w borach i lasach (6,5\% wobec 3,9\% i 3,6\%). Różnił się też istotnie pomiędzy klasami wieku; w drzewostanach najmłodszych $(9,1 \%)$ był średnio trzy razy większy niż w kolejnych klasach wieku (od 2,7 do 3,6\%). W rezerwatach miąższość martwych pni stanowiła od 4,3 do $26 \%$ miąższości drzewostanów (średnio 12,6\%). Miąższość posuszu stojącego, posuszu leżącego oraz całkowita miąższość martwego drewna nie były związane z miąższością żywych drzew. Słabą negatywną zależność wykryto tylko $\mathrm{w}$ przypadku miąższości pniaków $(r$ Pearsona $=-0.31 ; p<0,001)$.

Bogactwo taksonomiczne drzew $\mathrm{w}$ drzewostanach gospodarczych było większe niż bogactwo taksonomiczne martwego drewna $-5,8$ wobec 4,1 taksonów ( $F=227,6$; $p<0,001)$. Wzorzec ten był uniwersalny - dotyczył w mniejszym lub większym stopniu wszystkich frakcji martwego drewna oraz wszystkich badanych typów siedliskowych i klas wieku. W drzewostanach gospodarczych udział niektórych taksonów w całkowitej miąższości posuszu różnił się od ich udziału w miąższości żywych drzew (Fig. 3). W puli martwego drewna było procentowo mniej głównych drzew lasotwórczych - sosny i dębów - niż w drzewostanie, za to więcej taksonów towarzyszących, np. jesionu, brzóz, świerka. 
Wśród gatunków towarzyszących były jednak i takie, których brakowało w martwym drewnie: graby, buki i dęby czerwone były niemal nieobecne w posuszu stojącym i leżącym przy ich około $10 \%$ udziale w miąższości drzewostanu.

Grubość żywych drzew różniła się znacznie od grubości martwego drewna. Posusz (stojący i leżący) charakteryzował się mniejszymi grubościami w porównaniu z żywymi drzewami, natomiast pniaki cechowała przeciwna tendencja: pniaków cienkich było stosunkowo mało, a pniaki grube występowały licznie (Ryc. 6). Największe różnice pomiędzy grubością żywego i martwego drewna (z wyłączeniem pniaków) odnotowano dla dębów i sosny; mniejsze różnice istniały dla jesionu, modrzewia, lipy, brzóz i olszy, natomiast brak wyraźnych różnic stwierdzono dla osiki, grabu, buka i świerka (powyższe porównanie przeprowadzono tylko dla gatunków reprezentowanych przez co najmniej 20 sztuk posuszu, łącznie stojącego i leżącego).

\section{DYSKUSJA}

Puszcza Niepołomicka została zaproponowana jako Obszar Specjalnej Ochrony Ptaków już w 2002 r. Obszar ten utworzono dwa lata później rozporządzeniem Ministra Ochrony Środowiska, jednak dopiero w 2014 r. ustanowiono dla niego plan zadań ochronnych. W planie znalazł się zapis o docelowej ilości martwego drewna w wysokości $5 \mathrm{~m}^{3} \mathrm{ha}^{-1}$ w drzewostanach sosnowych i $20 \mathrm{~m}^{3} \mathrm{ha}^{-1} \mathrm{w}$ drzewostanach grądowych, przy czym wartości te odnosiły się tylko do drzewostanów w wieku powyżej 50 lat i nie uwzględniały pniaków (ZARZĄDZENIE 2014).

Miąższość stojącego posuszu i kłód, jaką zanotowano w lasach zagospodarowanych Puszczy Niepołomickiej, wyniosła niemal $7 \mathrm{~m}^{3} \mathrm{ha}^{-1}$ i nie różniła się między lasami, borami i olsami. Była to wartość nieco większa od oczekiwanej dla drzewostanów sosnowych i znacznie mniejsza od oczekiwanej dla lasów grądowych na terenie Obszaru Specjalnej Ochrony Ptaków (ZARZĄDZENIE 2014). W porównaniu z wynikami ogólnopolskiej inwentaryzacji przeprowadzonej w latach 2014-2018, na jednym hektarze zagospodarowanej części Puszczy Niepołomickiej było o $0,6 \mathrm{~m}^{3}$ mniej martwego drewna niż przeciętnie w całym kraju oraz o 1,6 $\mathrm{m}^{3}$ więcej niż w krainie małopolskiej (BIURO URZĄDZANIA LASU 2019). Martwego drewna w Puszczy Niepołomickiej było również nieco więcej niż kilka lat wcześniej w lasach na obszarach Natura 2000 w Nadleśnictwie Strzelce Opolskie, gdzie w 2011 r. stwierdzono $5,5 \mathrm{~m}^{3} \mathrm{ha}^{-1}$ (BANAŚ i in. 2014).

W planie zadań ochronnych dla Puszczy Niepołomickiej zaskakuje pominięcie młodszych drzewostanów. W polskich parkach narodowych w drzewostanach najmłodszych jest najwięcej martwego drewna (BIURO URZĄDZANIA LASU 2019) i jest to tendencja dobrze znana z lasów naturalnych, w których ilość martwego drewna zwiększa się po zajściu zaburzenia w warstwie drzew (GARBARINO $\mathrm{i}$ in. 2015). Zatem właśnie w młodszych drzewostanach na obszarach Natura 2000 powinno być obecne martwe drewno pozostawione w trakcie cięć rębnych, przy czym szczególnie cenne byłyby całe pnie lub fragmenty pni grubych drzew. Nasze wyniki pokazują jednak, że w trakcie cięć rębnych dochodzi nawet do zmniejszenia ilości martwego drewna. Może o tym świadczyć jego mniejsza miąższość 
w drzewostanach pierwszych dwóch klas wieku w porównaniu z drzewostanami w V klasie i starszymi. Podobna prawidłowość obserwowana jest we wszystkich lasach pozostających pod zarządem Lasów Państwowych (BiURo UrZąDZania Lasu 2019). Tymczasem, jeśli martwe drewno o dużych rozmiarach nie pozostanie na powierzchni zrębów, to nie będzie go w tych miejscach przez najbliższe kilkadziesiąt lat, do czasu, kiedy nowe pokolenie drzew uzyska odpowiednie rozmiary. Może to nastąpić, jak wskazują uzyskane przez nas wyniki, dopiero po osiągnięciu IV klasy wieku. Objętość posuszu stojącego i kłód była w tych drzewostanach większa o prawie $3 \mathrm{~m}^{3} \mathrm{ha}^{-1}$ niż w drzewostanach III klasy wieku.

Pomimo bardzo małej ilości martwego drewna w lasach Puszczy Niepołomickiej nasze wyniki sugerują, że zwiększyła się ona w ostatnich latach. Przemawia za tym porównanie zaawansowania rozkładu posuszu stojącego i kłód z zaawansowaniem rozkładu pniaków. W pierwszych dwóch klasach rozkładu liczba posuszu i kłód jest nawet nieznacznie większa od liczby pniaków, natomiast dwie najbardziej zaawansowane klasy rozkładu reprezentuje znacznie więcej pniaków niż posuszu i kłód. Podobne znaczące zmiany w proporcjach trzech frakcji martwego drewna w kolejnych klasach rozkładu odnotowano również w przypadku objętości. Nie dysponujemy danymi z Puszczy Niepołomickiej na temat tempa rozkładu pniaków, posuszu stojącego i kłód, ale większość badań wskazuje, że pniaki różnych gatunków rozkładają się nieco szybciej niż kłody, albo nie ma różnic w szybkości ich rozkładu (JANISCH i in. 2005; ToBIN $i$ in. 2007). Uzasadnione wydaje się zatem przypuszczenie, że zwiększanie ilości martwego drewna zachodziło jeszcze przed zatwierdzeniem planu zadań ochronnych w 2014 r.

Najwięcej martwego drewna na terenie Puszczy Niepołomickiej było w lasach z panującymi olszą czarną i jesionem wyniosłym. Są to lasy, które w klasyfikacji siedlisk leśnych zaliczane są do lasu mieszanego bagiennego, olsu typowego i olsu jesionowego. Oba gatunki panują też na sporych powierzchniach lasu mieszanego wilgotnego oraz lasu wilgotnego. Powierzchniowo stanowią one $11 \%$ lasów Puszczy Niepołomickiej (BiURo URZĄZZANIA LASU 2011). Zaskakuje zupełne pominięcie tych lasów w zarządzeniu ustanawiającym plan zadań ochronnych, bo nie są to ani grądy ani też drzewostany sosnowe. Miąższość martwego drewna była w tych bagiennych lasach dwukrotnie większa niż w drzewostanach sosnowych i o ponad połowę większa niż w grądach. Oznacza to, że te pominięte w zarządzeniu lasy spełniają obecnie najważniejszą rolę w kształtowaniu zasobów martwego drewna w Puszczy. Dwie są prawdopodobnie przyczyny tak dużej ilości martwego drewna na siedliskach bagiennych i części siedlisk wilgotnych, gdzie panują olcha czarna i jesion. Pierwszym jest masowe zamieranie jesionów, którego pierwsze symptomy w Puszczy Niepołomickiej nastąpiły po 2000 r. (KowALSKI 2006), a drugim ograniczona dostępność podmokłych terenów. Są one poprzecinane rowami odwadniającymi, które utrudniają transport pozyskanego drewna. Prawdopodobnie $\mathrm{w}$ związku z tym spora część z dużej liczby martwych jesionowych pni pozostała na miejscu. Ograniczona dostępność terenu jest zapewne także przyczyną nieco większego udziału olchy w puli martwego drewna niż w zasobności drzewostanów.

W kształtowaniu zasobów martwego drewna ważne jest zapewnienie reprezentacji możliwie największej liczby gatunków drzew, ponieważ drewno każdego gatunku może być zasiedlane przez nieco inny zestaw organizmów saproksylicznych (FALIŃsKi \& MuŁENKO 1996; Jonsell i in. 2007; Gossner i in. 2016). Drzewa panujące w drzewostanach Puszczy 
Niepołomickiej, sosna, dęby i olcha, miały też największy udział w zasobach martwego drewna. $\mathrm{Z}$ kolei drewno jesionowe, osikowe i brzozowe było pozostawiane w lesie częściej niż wynikałoby to z udziału tych gatunków w składzie drzewostanów. Odwrotna sytuacja była w przypadku buka, grabu i lipy, których łączny udział w miąższości drzewostanów wynosił kilkanaście procent. Tymczasem wśród martwych pni lipa była nielicznie reprezentowana, a buki i graby były niemal nieobecne. Szczególnie niekorzystna jest znikoma ilość drewna grabowego, ponieważ jest to jeden z najważniejszych gatunków drzew dla różnorodności biologicznej organizmów saproksylicznych (FALIŃSKI \& MUŁENKO 1996; GosSNER i in. 2016). Brak martwych grabów i buków w Puszczy Niepołomickiej jest zapewne związany z zapotrzebowaniem na opał wśród mieszkańców miejscowości otaczających Puszczę.

Pniaki są rzadko uwzględniane w badaniach nad martwym drewnem, ponieważ są uważane za substrat o słabej jakości dla organizmów saproksylicznych (SIITONEN i in. 2000; CASTAGNERI $i$ in. 2010). W lasach naturalnych miąższość pniaków jest niewielka w porównaniu z innymi formami martwego drewna i mogą być pominięte, ale w lasach, w których prowadzona jest gospodarka leśna, ich udział może być spory i stały. W Puszczy Niepołomickiej pniaki stanowiły około $1 / 4$ objętości martwego drewna. Ich udział był znacznie większy pod względem liczby fragmentów martwego drewna i wahał się od 2/3 do 3/4. Inną cechą wyróżniającą pniaki była ich większa średnica w porównaniu z grubością posuszu stojącego i kłód. W ostatnich latach pojawiły się wyniki badań wskazujące, że ta forma martwego drewna, zwłaszcza w postaci grubych pniaków, również może odgrywać ważną rolę dla organizmów saproksylicznych (HJÄLTEN i in. 2010; BRIN i in. 2013).

Wśród martwych pni najwięcej było tych cienkich, o kilkunastocentymetrowej grubości, a grubych okazów było bardzo mało. Jednym z podstawowych powodów niedostatku grubych, martwych pni był z pewnością fakt, że w drzewostanach Puszczy Niepołomickiej, użytkowanych gospodarczo, zdecydowanie przeważają drzewa o grubości nie przekraczającej $30 \mathrm{~cm}$. Tylko kilka procent drzew ma grubość powyżej pół metra. Drugim czynnikiem jest wartość rynkowa drewna zależna od jego grubości. Drewno wielkowymiarowe o grubości ponad $24 \mathrm{~cm}$ osiąga kilka razy wyższe ceny niż cieńsze drewno średniowymiarowe i z tego powodu to drugie jest częściej pozostawiane w lesie. Zapewne dlatego znikoma była ilość martwych pni i ich fragmentów grubszych niż $0,5 \mathrm{~m}$. Niedostatek grubych martwych pni stwierdzony w Puszczy Niepołomickiej nie jest niczym wyjątkowym w lasach gospodarczych (FridMAn \& WALHEIM 2000; SWEenEY i in. 2010; BILEK i in. 2011; BöLÖNI i in. 2017). Odzwierciedla to powszechny konflikt interesów między ochroną przyrody a gospodarczym użytkowaniem lasu, który niełatwo rozwiązać.

Grube martwe pnie poszczególnych taksonów były usuwane z lasu z różną intensywnością. Największą redukcję grubości martwych pni w porównaniu z grubością żywych drzew zanotowano dla dębów i sosny, a najmniejszą dla brzóz, jesionu, lipy i osiki. Zauważone różnice między taksonami są także spowodowane czynnikami ekonomicznymi. Pozyskanie prawie wszystkich grubych pni dębowych i sosnowych jest związane z ich wysoką wartością. Grube osiki, brzozy i lipy były pozyskiwane ze słabszą intensywnością, ponieważ drewno tych taksonów osiąga niższe ceny. W przypadku jesionu mamy do czynienia z jeszcze inną sytuacją. $Z$ uwagi na mniejszą dostępność siedlisk, na których ten gatunek rośnie, wyższe są koszty jego pozyskania. 
Wyniki pomiarów martwego drewna w Puszczy Niepołomickiej wskazują na trzy problemy związane $\mathrm{z}$ jego akumulacją w lasach gospodarczych, przed którymi postawiono zadania z zakresu ochrony przyrody. Pierwszym jest stosunkowo niewielka ilość martwego drewna, drugim - niedostatek martwego drewna o dużych rozmiarach, a trzecim - ograniczenie jego bogactwa gatunkowego. Można wskazać kilka kierunków działań, które przyczyniając się do zwiększenia zasobów martwego drewna, miałyby mniejsze znaczenie dla uszczuplenia ekonomicznego wyniku gospodarstwa leśnego: (1) dalsza akumulacja martwego drewna może następować w lasach na siedliskach bagiennych i wilgotnych, do których jest ograniczony dostęp; (2) wzbogacenie puli martwego drewna może w dalszym ciągu odbywać się poprzez ograniczenie eksploatacji gatunków mniej cennych z ekonomicznego punktu widzenia: brzozy, osiki i lipy; (3) ograniczeniu powinna ulec eksploatacja grabu; (4) brak grubego martwego drewna może być częściowo zrekompensowany poprzez pozostawianie w lesie wypróchniałych, odziomkowych fragmentów pni o niewielkiej ekonomicznej wartości.

Podziękowania. Badania były finansowane z środków Państwowego Gospodarstwa Leśnego Lasy Państwowe w ramach zlecenia badawczego pt. Ksztattowanie się zasobów martwego drewna w siedliskach przyrodniczych $w$ warunkach prowadzenia zrównoważonej gospodarki leśnej (Nr OR.271.3.9.215) oraz środków statutowych Instytutu Botaniki im. W. Szafera Polskiej Akademii Nauk. Autorzy dziękują również Nadleśnictwu Niepołomice za umożliwienie prowadzenia badań na terenie Puszczy Niepołomickiej oraz wszystkim osobom, które brały udział w pracach terenowych.

\section{LITERATURA}

Angelstam P., Naumov V., Elbakidze M., Manton M., Priednieks J. \& Rendenieks Z. 2018. Wood production and biodiversity conservation are rival forestry objectives in Europe's Baltic Sea Region. - Ecosphere 9(3): e02119.

Banaś J., BujoczeK L., Zięba S. \& Drozd M. 2014. The effects of different types of management, functions, and characteristics of stands in Polish forests on the amount of coarse woody debris. - European Journal of Forest Research 133: 1095-1107.

Bednarz Z. 1981. Bory Puszczy Niepołomickiej. - Studia Ośrodka Dokumentacji Fizjograficznej 9: 89-115.

Bilek L., Remes J. \& ZahradniK D. 2011. Managed vs. unmanaged. Structure of beech forest stands (Fagus sylvatica L.) after 50 years of development, Central Bohemia. - Forest Systems 20: 122-138.

BiURo URZĄDZANIA LASU i GeOdEZJ LEŚNEJ 2019. Wielkoobszarowa inwentaryzacja stanu lasów. Wyniki za okres 2014-2018. Sękocin Stary.

Biuro UrZądzania Lasu i GeodezjI Leśnej OdDZią w Krakowie 2011. Prognoza oddziaływania na środowisko projektu planu urządzenia lasu Nadleśnictwa Niepołomice na okres gospodarczy od 1 stycznia 2012 r. do 31 grudnia 2021 r. Kraków.

BÖLÖNI J., ÓDOR P., ÁDÁm R., KeEton W. S. \& AsZALÓs R. 2017. Quantity and dynamics of dead wood in managed and unmanaged dry-mesic oak forests in the Hungarian Carpathians. - Forest Ecology and Management 399: 120-131.

Brin A., Bouget C., Valladares L. \& Brustel H. 2013. Are stumps important for the conservation of saproxylic beetles in managed forests? - Insights from a comparison of assemblages on logs and stumps in oak-dominated forests and pine plantations. - Insect Conservation and Diversity 6: 255-264. 
BRUnet J., Fritz Ö. \& Richnau G. 2010. Biodiversity in European beech forests - a review with recommendations for sustainable forest management. - Ecological Bulletins 53: 77-94.

Castagneri D., Garbarino M., Berretti R. \& Motta R. 2010. Site and stand effects on coarse woody debris in montane mixed forests of Eastern Italian Alps. - Forest Ecology and Management 260: 1592-1598.

Christensen M., Hahn K., Mountford E. P., Ódor P., Standovár T., Rozenbergar D., Diaci J., WiJDeven S., Meyer P., Winter S. \& VRska T. 2005. Dead wood in European beech (Fagus sylvatica) forest reserves. - Forest Ecology and Management 210: 267-282.

Czuraj M. 1991. Tablice miąższości kłód odziomkowych i drzew stojących. s. 362. Państwowe Wydawnictwo Rolnicze i Leśne, Warszawa.

ĆwıKowa A. 1981. Lasy łęgowe Puszczy Niepołomickiej. - Studia Ośrodka Dokumentacji Fizjograficznej 9: $131-149$.

ERIKSSON M., LILJA S. \& RoININEN H. 2006. Dead wood creation and restoration burning: Implications for bark beetles and beetle induced tree deaths. - Forest Ecology and Management 231: 205-213.

FALIŃsKi J. B. \& MuŁENKo W. (red.). 1996. Cryptogamous plants in the forest communities of Białowieża National Park. Functional groups analysis and general synthesis (Project CRYPTO 3). - Phytocoenosis 8 (N.S.), Archivum Geobotanicum 6: 1-224.

FeliksiK E. 1981. Olesy Puszczy Niepołomickiej. - Studia Ośrodka Dokumentacji Fizjograficznej 9: 151-157.

FerChMin M. 1976. Oles Carici elongatae-Alnetum oraz zbiorowiska ze związu Salicion i Alno-Padion w północnej części Puszczy Niepołomickiej. - Studia Naturae, Seria A 13: 107-142.

Fridman J. \& WALHEIM M. 2000. Amount, structure, and dynamics of dead wood on managed forestland in Sweden. - Forest Ecology and Management 131: 23-36.

Garbarino M., Marzano R., Shaw J. D. \& Long J. N. 2015. Environmental drivers of deadwood dynamics in woodlands and forests. - Ecosphere 6(3): 30.

Gazda A. \& Szlaga A. 2008. Obce gatunki drzewiaste w północnym kompleksie Puszczy Niepołomickiej. - Sylwan 152(4): 58-67.

Gossner M. M., Wende B., Levick S., Schall P., Floren A., Linsenmair K. E., StefFan-Dewenter I., SchiLze E.-D. \& WeISSER W. W. 2016. Deadwood enrichment in European forests - Which tree species should be used to promote saproxylic beetle diversity? - Biological Conservation 201: 92-102.

GruszczyK A. 1981. Siedliskowe typy lasu Puszczy Niepołomickiej. - Studia Ośrodka Dokumentacji Fizjograficznej 9: 205-216.

Gutowski J. M., Bobiec A., Pawlaczyk P. \& Zub K. 2004. Drugie życie drzewa. s. 245. WWF Polska, Warszawa - Hajnówka.

Hammer Ø., Harper D. A. T. \& Ryan P. D. 2001. PAST: Paleontological statistics software package for education and data analysis. - Palaeontologia Electronica 4(1): 9pp.

HJältén J., Stenbacka F. \& Andersson J. 2010. Saproxylic beetle assemblages on low stumps, high stumps and logs: Implications for environmental effects of stump harvesting. - Forest Ecology and Management 260: 1149-1155.

Jacobsen J. B., Vedel S. E. \& Thorsen B. J. 2013. Assessing costs of multifunctional NATURA 2000 management restrictions in continuous cover beech forest management. - Forestry 86: 575-582.

JAKOBY O., RADEMACHER C. \& GRIMM V. 2010. Modelling dead wood islands in European beech forests: how much and how reliably would they provide dead wood? - European Journal of Forest Research 129: 659-668. 
Janisch J., Harmon M. E., Chen H., Fasth B. \& SeXton J. 2005. Decomposition of coarse woody debris originating by clearcutting of an old-growth conifer forest. - Ecoscience 12: 151-160.

Johansson T., Gibb H., Hilszczański J., Pettersson R. B., Huältén J., Atleggrim O., Ball J. P. \& DANELl K. 2006. Conservation-oriented manipulations of coarse woody debris affect its value as habitat for spruce-infesting bark and ambrosia beetles (Coleoptera: Scolytinae) in northern Sweden. - Canadian Journal of Forest Research 36: 174-185.

Jonsell M., Hansson J. \& WedMo L. 2007. Diversity of saproxylic beetle species in logging residues in Sweden - comparisons between tree species and diameters. - Biological Conservation 138: 89-99.

KOWALSKI T. 2006. Chalara fraxinea sp. nov. associated with dieback of ash (Fraxinus excelsior) in Poland. - Forest Pathology 36: 264-270.

Maiorano L., Amori G., Montemaggiori A., Rondinini C., Santini L., Saura S. \& Boitani L. 2015. On how much biodiversity is covered in Europe by national protected areas and by the Natura 2000 network: insights from terrestrial vertebrates. - Conservation Biology 29: 986-995.

Maser C., Tarrant R. F., Trappe J. M. \& Franklin J. F. 1988. From the forest to the sea: a story of the fallen trees. General Technical Report PNW-GTR-229. s. 153. U.S. Department of Agriculture, Forest Service, Pacific Northwest Research Station, Portland.

MÜLLER J. \& BÜTLER R. 2010. A review of habitat thresholds for dead wood: a baseline for management recommendations in European forests. - European Journal of Forest Research 129: 981-992.

Myczkowski S. 1981. Lasy grądowe Puszczy Niepołomickiej. - Studia Ośrodka Dokumentacji Fizjograficznej 9: 117-130.

Pasierbek T., Holeksa J., Wilczek Z. \& Żywiec M. 2007. Why the amount of dead wood in Polish forest reserves is so small? - Nature Conservation 64: 65-71.

RANIUS T. \& FAHRIG L. 2006. Targets for maintenance of dead wood for biodiversity conservation based on extinction thresholds. - Scandinavian Journal of Forest Research 21: 201-208.

Ranius T., Ekvall H., Jonsson M. \& Bostedt G. 2005. Cost-efficiency of measures to increase the amount of coarse woody debris in managed Norway spruce forests. - Forest Ecology and Management 206: $119-133$.

Sabatini F. M., Burrascano S., Keeton W. S., Levers C., Lindner M. i in. 2018. Where are Europe's last primary forests? - Diversity and Distribution 24: 1426-1439.

SCHROEDER L. M. \& LiNDELÖW Å. 2002. Attacks on living spruce trees by the bark beetle Ips typographus (Col. Scolytidae) following a storm-felling: a comparison between stands with and without removal of wind-felled trees. - Agricultural and Forest Entomology 4: 47-56.

Seibold S., Bässler C., Brandl R., Gossner M. M., Thorn S., Ulyshen M. D. \& Müller J. 2015. Experimental studies of dead-wood biodiversity - A review identifying global gaps in knowledge. - Biological Conservation 191: 139-149.

SIITONEN J. 2001. Forest management, coarse woody debris and saproxylic organisms: Fennoscandian boreal forests as an example. - Ecological Bulletins 49: 11-41.

Sittonen J., Martikainen P., Punttila P. \& Rauh J. 2000. Coarse woody debris and stand characteristics in mature managed and old-growth boreal mesic forests in southern Finland. - Forest Ecology and Management 128: 211-225.

Stokland J., Sirtonen J. \& Jonsson B. G. 2012. Biodiversity in dead wood. s. 524. Cambridge University Press, Cambridge.

Sweeney O. F. McD., Martin R. D., Irwin S., Kelly T. C., O’Halloran J., Wilson M. W. \& McEvoy P. M. 2010. A lack of large-diameter logs and snags characterises dead wood patterns in Irish forests. - Forest Ecology and Management 259: 2056-2064. 
Tobin B., Black K., McGurdy L. \& Nieuwenhuis M. 2007. Estimates of decay rates of components of coarse woody debris in thinned Sitka spruce forests. - Forestry 80: 455-469.

Ylisirniö A.-L., Mönkkönen M., Hallikainen V., Ranta-Maunus T. \& Kouki J. 2016. Woodland key habitats in preserving polypore diversity in boreal forests: Effects of patch size, stand structure and microclimate. - Forest Ecology and Management 373: 138-148.

ZARZĄDZENIE 2014. Zarządzenie regionalnego dyrektora ochrony środowiska w Krakowie z dnia 8 sierpnia 2014 r. w sprawie ustanowienia planu zadań ochronnych dla obszaru Natura 2000 Puszcza Niepołomicka PLB120002 (Dz. U. Woj. Małopolskiego z 2014 r. poz. 4390).

\section{SUMMARY}

Deadwood plays an important role in forest ecosystems. Since only small areas of European forests protected in national parks and reserves contain a sufficient amount of deadwood for saproxylic organisms, it was realized that commercial forests should play a greater role in restoring its resources. This has been made possible in the Natura 2000 network. A situation where nature conservation and wood production are carried out in the same area leads to an inevitable conflict between biological and economic benefits. We were interested in how this problem can be solved in a large Natura 2000 forested area in southern Poland. We focused on the relationship between the properties of managed stands and the quantity and quality of deadwood.

We measured diameter and height (length) and calculated the volume of living trees and deadwood pieces thicker than $10 \mathrm{~cm}$ in 187 plots $(0.4$ ha each) distributed regularly over the whole Niepołomice Forest (Fig. 1). Three fractions of deadwood were distinguished: snags, logs and stumps. Each piece of deadwood was identified to species and assessed on a five-stage scale of decomposition.

On average, 184 pieces of deadwood were recorded per 1 ha of managed forests. Logs were three times more numerous than snags, and stumps were 2.5 times as numerous as logs and snags put together. The density of snags and logs in black alder swamp forests was higher than in other forest types. No relationship was found between the density of snags and logs and stand age. Stump density was higher in younger stands than in older ones (Fig. 4).

The total volume of snags and logs was $6.7 \mathrm{~m}^{3} \mathrm{ha}^{-1}$ on average. This was $0.6 \mathrm{~m}^{3} \mathrm{ha}^{-1}$ less than the average for managed stands in Poland as a whole. The volume was $9.2 \mathrm{~m}^{3} \mathrm{ha}^{-1}$ if stumps were included. The volume ratio of snags, logs and stumps was 3:3:2. In alder forests the volume of deadwood was higher than elsewhere, as a result of massive dying of ash and the lower accessibility of swamp habitats. The volume of stumps changed with stand age, the values being highest in the youngest stands. The volume of snags and logs was lower in the youngest than in harvested stands (Fig. 4). This means that the amount of deadwood is reduced during final cutting. The share of deadwood in total stand volume was $4.1 \%$ on average. In alder forests it was significantly higher than in other forests. It also differed between age classes. In the youngest stands the share of deadwood (9.1\%) was on average three times higher than in the subsequent age classes.

The thickness of living trees differed significantly from that of snags and logs. The latter were much thinner. Stumps were thicker than living trees (Fig. 6). The greatest differences in thickness between living wood and deadwood were recorded for pedunculate and sessile oak and Scots pine, while no differences were found for trembling aspen, silver and downy birch, common hornbeam, common beech and Norway spruce.

The share of dominants (Scots pine, oak) was greater in the total volume of living trees than in the total volume of deadwood. In contrast, the share of some accompanying species (e.g. ash, birch, spruce) was greater in the pool of deadwood. Deadwood of other accompanying species (hornbeam, beech, red oak) was almost absent even though they constituted $10 \%$ of stand volume (Fig. 3). The lack of dead hornbeam and beech probably was due to their common use for fuel in villages surrounding the Niepołomice Forest. On the other hand, the excess of birch and aspen in the pool of deadwood is connected with their low market value. 
Individual fractions of deadwood differed in average degree of decomposition. That value was lowest for snags, intermediate for logs, and highest for stumps (Tab. 1, Fig. 7). In all stages of decomposition, stumps were more numerous than snags and logs; their prevalence increased with the advancement of decomposition; in the last two stages of decomposition, stump volume was even greater than the volume of snags and logs taken together (Fig. 7).

Our results point to three problems related to deadwood accumulation in managed forests faced with nature protection tasks: low amount of deadwood, the considerable prevalence of thin pieces of deadwood and the shortage of thick deadwood, and limited representation of the full species composition in the pool of deadwood. Several solutions to these problems can be proposed to enlarge the pool of deadwood while respecting the economic conditions of forestry: (1) deadwood can be accumulated in places with limited accessibility, such as marshy and wet habitats and steep slopes; (2) exploitation of economically less valuable species (birch, aspen, Lime is in the Oline Atlas of British and Irish Flora can be reduced; (3) exploitation of hornbeam and beech can be reduced, with other sources of energy used instead of fuelwood; and (4) the shortage of thick pieces of deadwood in a forest can be compensated by leaving basal and rotten fragments of trunks in the form of high stumps.

Wptynęto: 07.02.2020 r.; przyjęto do druku: 26.03.2020 r. 